\title{
Can Constitutive Rules Create a Practice?*
}

Giuseppe Lorini**

1 Constitutive rules and sense of game. 2 Chess-like game vs. chess-like rite. 3 Rule-constituted activity vs. practice. 4 Averroës' impossible research. References

\begin{abstract}
The author investigates the role of constitutive rules in the construction of social reality. He denies that constitutive rules are a sufficient condition of a practice such as a chess game. To create a new practice with rules, it is necessary that there already be the grammar of this practice, that is, the sense of this practice (for example, the sense of game). It is the grammar of a practice and not its constitutive rules that determines the nature of a practice. The sense of a practice cannot be created by constitutive rules.
\end{abstract}

Key words: constitutive rules, practice, social ontology, institutional fact.

\section{CONSTITUTIVE RULES AND SENSE OF GAME}

This essay concerns social ontology. In social ontology, a fundamental distinction is that (proposed by the American philosopher John R. Searle) between brute facts and institutional facts.

For Searle $(1969,51)$, institutional facts are facts which, unlike brute facts, presuppose the existence of certain human "institutions". The adjective

* The present article was originally published in Praxis Filosófica and is available at: http:// praxis.univalle.edu.co/index.php/filosofica/article/view/1930/2971. In the event of a citation, please reference the original publication. (Esta nota foi alterada a pedido do autor.)

** Giuseppe Lorini teaches Philosophy of Law and General Theory of Law at the University of Cagliari (Italy) since 2005. He taught also at the University of Camerino (Italy) and the University of Pavia (Italy). He took his $\mathrm{PhD}$ in "Analytical Philosophy and General Theory of Law" in 1997 at the State University of Milan (Italy) with a thesis entitled Dimensions of the Institutional (Dimensioni dell'istituzionale). He was visiting professor at the Universidad Internacional de la Andalucía (Spain), the Universidad de Oviedo (Spain), the Uniwersitet Gdański [University of Gdansk) (Poland), the University of Nagoya (Japan). He was visiting scholar at the University of California at Berkeley (USA) and the Universidad de Sevilla (Spain). He is a member of the editorial board of the philosophical journal "Argumenta. Journal of Analytic Philosophy" and a member of the International Advisory Board of the Polish journal "Ruch Prawniczy, Ekonomiczny i Socjologiczny" ("The Legal, Economical and Sociological Journal"). Main interests: philosophy of normativity, social ontology, philosophy of deontic logic, legal anthropology and legal ethology. E-mail: lorini@unica.it (Esta nota foi alterada a pedido do autor.) 
'institutional' that Searle uses to qualify kind of fact derives from this definition of institutional facts.

If one ignores this distinction one may commit the error of confusing institutional status (like being a Lord-Mayor, Judge and Bishop) and objects that are only indicators of status. Jonathan Swift $(1960,283)$ describes this confusion genially in the following way: "These animals, which are vulgarly called suits of clothes, or dressed, do according to certain compositions receive different appellations. If one of them be trimmed up with a gold chain, and a red gown, and a white rod, and a great horse, it is called a Lord-Mayor; if certain ermines and furs be placed in a certain position, we style them a Judge, and so an apt conjunction of lawn and black satin we entitled a Bishop".

In order to characterize the concept of institutional fact and to distinguish institutional facts from brute facts, Searle uses the concept of a "constitutive rule". In fact, for Searle $(1969,51)$, "institutions" are systems of constitutive rules.

Searle distinguishes two different sorts of rules: regulative rules and constitutive rules. For Searle $(1969,34)$, "regulative rules regulate a preexisting activity, an activity whose existence is logically independent of the rules", whereas "constitutive rules constitute [...] an activity the existence of which is logically dependent on the rules". For example, "the rules of football or chess [...] do not merely regulate playing football or chess, but as it were they create the very possibility of playing such games".

My point of departure is the thesis that constitutive rules create the possibility of new forms of behavior. The question that I ask in the present essay is: It is really true that a new (type of) institutional activity can be created only by constitutive rules? This essay investigates the way in which an institutional activity is created by means of constitutive rules, but also the limits and the conditions of the creation of institutional activities by constitutive rules. In other words, the question is, Are the constitutive rules of a practice a necessary and sufficient condition of the type of practice that is its object? ${ }^{1}$

My answer is this: constitutive rules can create the possibility of new forms of behavior (a new rule-constituted activity), but they can not themselves create a new practice. They can not be a necessary and sufficient condition of a practice.

In order to explain and demonstrate this thesis, I begin by looking at the thesis argued for Searle $(1969,33-34)$ :

The activity of playing chess is constituted by acting in accordance with the appropriate rules.

Is it true, however, that the activity of playing chess consists in acting in accordance with the constitutive rules of chess? In other words, does the activity of playing chess consist in acting in accordance with the constitutive rules that constitute the possible moves and the values of the chess pieces? 
('Constitutive rules of chess' I understand to be those rules that are specific to the game of chess; in other terms, all the rules that define the possible moves in the game and the value of chess pieces. ${ }^{2}$ It is those rules that distinguish the game of chess from soccer or checkers.)

Another philosopher, Hubert Schwyzer has criticized the Searle's thesis. Schwyzer doesn't deny that chess is a game played by acting in conformity to the rules of the game. In other words, Schwyzer doesn't deny that the game of chess is a rule-governed activity. What he denies is:

first, that the sense of game characterising the activity of playing chess derives from acting in conformity to the rules of the game;

second, that the sense of game characterising the institution called 'chess' is constituted by the rules of chess.

(i) First, Schwyzer denies that the sense of game characterising the activity of playing chess consists in acting in conformity to the rules of chess:

There is all the difference in the world between saying that the game of chess is defined by its rules, or that chess is a game played in accordance with these rules, and saying that the activity of playing chess is constituted by action in accordance with these rules, or that the rules define that activity. The former is unexceptionable, the latter false (SCHWYZER 1969, 454).

For Schwyzer $(1969,464)$, "playing chess does not consist in acting in accordance with the rules. The rules do not explicate the concept of playing chess; they do not establish what it is to play chess." Acting in accordance with these rules isn't a sufficient condition for the fact that you are playing chess.

An similar observation occurs in Josef Schächter (1935). Schächter argues that it is not sufficient to act according to the rules of chess to play chess. In the case of a person who practices the rules of chess with his instructor, these two people are not playing chess. In Schächter's terminology, they are not "using" the rules, but only demonstrating them. Schächter writes:

In teaching chess, an instructor can proceed by practising with his pupil the rules of the game, in such a way that in the usual sequence (move - counter move) the pupil moves his pieces according to the prescribed rules. One may ask: are these two playing chess or not? [...] We must say that they are, for all the rules are being obeyed. But in another sense we might say that they are not, for they are playing merely to demonstrate the rules of the game, they are doing its grammar. So long as it is viewed merely as demonstrating rules, it does not yet belong to the game; but as soon as we abandon the way of demonstration, we are playing chess. (To decide whether it is a case of demonstrating or actually usingthe rules, one can do no more than ask the players or infer their intentions from their behaviour.) 
(ii) Second, Schwyzer denies, also, that the sense of game characterising the game of chess is constituted by the rules of chess. As Schwyzer writes:

That chess is a game is in no way a rule of the game (SCHWYZER 1969, 463).

The problem here is: in what does the sense of game of an activity like playing chess consist?

\section{CHESS-LIKE GAME VS. CHESS-LIKE RITE}

Schwyzer explains and proves the apparently counterintuitive thesis that the sense of game isn't intrinsic to the activity constituted by the constitutive rules of chess, proposing a mental experiment:

Imagine the following. I have now been in Ruritania some time, and can speak the language tolerably well. One day I accompany my host with his family to a certain building, where a large number of people are sitting in a circle on the floor, murmuring among themselves agitatedly. In the center of the circle is a small table with two chairs, and on the table is a chessboard with chessmen arranged as for the beginning of a game. After a while, two men in elaborate clothes enter the room and seat themselves at opposite sides of the table; whereupon those sitting on the floor fall silent and watch intently. The men at the table then proceed, with what appears to be an air of great concentration, to move the chess pieces around on the board according to the rules of chess. It strikes me, however, that they play a rather wild game, and I can see no consistent strategy in the moves of either player. The excitement mounts until, after an hour or so, white mates black. Then everyone present, including both men at the table, shows signs of extreme relief; they mop their brows, smile and congratulate one another (SCHWYZER 1969, 456).

Continuing with his mental experiment, Schwyzer imagines that, on returning to home, he shows his own chess set to his host and he asks him to play chess. But here is the surprising reaction of his host to this request:

He turns pale, is horrified and appalled, and insists that I put it away immediately. "Blasphemer!" he exclaims. "Did you want to play at chess with me?" And did you forge that chess set?" (SCHWYZER 1969, 456).

Why did Schwyzer's host react in this way to the simple request to play chess? Schwyzer understands the reason of this excessive reaction when his host explains to him what the practice of chess consists of in Ruritania:

There is, he says, only one chess set for each community. Chess is enacted once every year by the priest of the community, for purposes of determining the will of the gods. If white mates black, the community and the crops will flourish; if black mates white, there will be trouble (SCHWYZER 1969, 457). 
Then, to the Schwyzer's question whether the white should always win, the host, once more shocked, answers in this way:

Chess is not a duel or a battle. It is a sacred rite. There is no winning or losing at all (SCHWYZER 1969, 457). ${ }^{3}$

Here the misunderstanding is revealed: in Ruritania, chess is not a game, but a religious rite that is enacted only once a year by the priest of the community. ${ }^{4}$ The rite of chess is not a form of competition: in the rite of chess, you can't win or loose, because victory and defeat don't compose the grammar of the rite.

Consequently, for the grammar of rite, in Ruritania's chess it doesn't make sense to talk of strategy.

In this mental experiment, Schwyzer focuses on the fact that the differences between the game of chess and the rite of chess are not determined by the constitutive rules of chess. Indeed, the activity of the two practices (rite of chess and game of chess) is governed by the same rules: the constitutive rules of chess.

But where then lies the difference between the two practices?

(i) The difference between the two practices doesn't appear on the brute level of description of the action. It is not perceivable in the observation of mere physical activities that compose the two practices.

Additionally, the difference between the two practices doesn't consist even in mental events in the minds of the players. Schwyzer writes:

The difference between the rite of chess and the game of chess lies not at all in what goes on at the board, nor in anything in the minds of those who make the moves (SCHWYZER 1969, 464).

(ii) The difference between the two practices doesn't appear even to the institutional level of description of the action. Indeed, the two practices, sharing the same system of rules, necessarily also share the same institutional support consisting in an activity according the constitutive rules of chess.

(iii) Instead, the difference between the two practices consists in the different role, in the different value, that the activity has in the everyday life of those who practice it:

The difference lies away from the board altogether, in what Wittgenstein calls the "role" of the activity in the lives of those for whom it is a practice (SCHWYZER 1969, 464).

For Schwyzer, it is the different grammar of the two activities that distinguishes the game of chess from the rite of chess. It is the grammar of a practice and not its constitutive rules that determines its nature, and consequently its sense of rite or its sense of game:

The nature of a given practice is defined not by its rules, but by its "grammar" (SCHWYZER 1969, 463). 
Schwyzer $(1969,463)$ believes that the fact "that chess is a game is in no way a rule of the game". It is a grammatical proposition. ${ }^{5}$ In this regard, he writes:

What makes chess-playing the kind of thing it is is a matter of what sorts of things it makes sense to say with respect to chess, of what sorts of things are, in a logical sense, relevant or appropriate to say with regard to chess (SCHWYZER 1969, 454)..

Schwyzer further argues:

It belongs to the grammar of "chess" that we can say such things as "Let's play chess", "That was a wise (a silly) move", we can ask who won or is winning, say "Bad luck" to the one and "Well played" to the other after the game is over; these ways of speaking are intrinsically relevant in the context of chess, not in the context of, say, Mass (SCHWYZER 1969, 455).

In the same way, the fact that chess presuppose skill belongs to the grammar of chess.

Similarly, it is because of its grammar that the rite of chess is different from the game of chess. The rite of chess, indeed, unlike the game of chess, is not a form of competition and, so, it doesn't make sense to talk in the rite of chess about victory and defeat, or even strategy.

For Schwyzer, the word 'grammar' in the phrase 'grammar of chess' has a very similar meaning to the term 'grammar' used in the ordinary schoolbook grammar. Similarly the grammar as a theory of syntax means that 'children' is a noun and 'play' is a verb and that it is meaningful to write 'The children play', but not 'The play children'; the grammar of a practice means that chess is a competition, and it means that it makes sense to say certain things with regard to chess, but not with regard to other practices.

Schwyzer's observation suggests that there is a level of institutional action (the level of the activity that has a sense of a practice, like a sense of game or a sense of rite), where the constitutive rules don't work.

With regard to the distinction between the concept of activity constituted by rules and the concept of practice, it is clear that acting in accordance with the rules of chess isn't sufficient, in order to play chess, in the same way that acting in accordance with the rules of soccer isn't sufficient in order to play soccer.

\section{RULE-CONSTITUTED ACTIVITY VS. PRACTICE}

In order to prove that institutional activities and institutions are not mere rule-constituted activities, Schwyzer invents a new rule-governed activity that isn't a practice: X-ing. Schwyzer writes:

Suppose I tell you I have created a new form of behaviour, invented a new practice, and these are the rules. No, it is not a 
game or competition of any kind, nor a rite or ceremony, nor is it in any sense a "way of doing something", as making a will is a way of providing for one's property after death, has that purpose built into it. It is a new practice altogether, called "X-ing"; it requires two participants, the "initiator" and the "respondent", and the procedure is as follows. First, the initiator signs his name on this special piece of paper called "the pad"; his signing his name there is called "launching". The respondent then has a choice: either he "submits", which is to do this, or he ... and so forth. The whole business is terminated when the respondent "declares" - that is, signs his name on the other side of the pad (SCHWYZER 1969, 464).

$X$-ing is a rule-governed activity, i.e. an activity whose nature consists in acting in conformity to its constitutive rules. Asks Schwyzer:

What is X-ing? An activity according to these rules (SCHWYZER 1969, 464).

But this activity has no other senses than this. It isn't a game or a rite. It isn't a way of doing something like a will is a "way of" distributing one's property after one's death. For Schwyzer, X-ing is a mere rule-governed activity that isn't a practice.

For Schwyzer, X-ing is not a practice for three different reasons.

(i) First, "X-ing hasn't a grammar" (Schwyzer 1969, 465). There aren't grammatical propositions on the nature of X-ing. Recovering the philosophy of Ludwig Wittgenstein, Schwyzer $(1969,454)$ defines the grammar of an activity as that "which makes it an activity of that kind". The grammar is the place of sense (for instance, sense of rite or sense of game) that conditions the possibility of being of a practice.

(ii) Second, there isn't any situation that counts as an appropriate situation to engage in X-ing (Schwyzer 1969, 465).

(iii) Third, X-ing hasn't any other sense than the sense of acting in accordance with its rules:

To act in accordance with those rules is not to do or to be engaged in anything other than just that, action in accordance with those rules (SCHWYZER 1969, 466).

Unlike X-ing, chess is, instead, an example of a rule-governed activity that is also a practice. Chess is an example of an activity that can be performed only by acting in accordance with constitutive rules, but whose sense doesn't exhaust itself in a simple behaviour that conforms to constitutive rules. Chess is a game, but that it is a game is not abducible by the constitutive rules of the game. The rules of chess don't permit the understanding of the sense of this activity. The sense of this activity transcends those rules that constitute the possibility of the game. 
Inow return to the initial question posed in this essay: Does the activity of playing chess consist in acting in accordance with the constitutive rules of chess?

My answer is negative. I believe playing chess doesn't consist only in acting in conformity to the rules of chess. It's obvious that chess is a game played by acting in conformity to its rules. It's impossible to play chess without the rules of chess. But it's no less true that to move in accordance to the rules of chess is not necessarily to play chess. A person who moves mechanically chess pieces without a strategy or without the goal of checkmate, isn't playing chess. It's even possible, following the rules of chess, to perform an activity totally different from and also grammatically incompatible with the game of chess, such as the rite of chess described by Schwyzer.

\section{AVERROËS' IMPOSSIBLE RESEARCH}

An epistemical thesis corresponds to my ontological thesis about the nature of institutional activity: if you don't know the grammar of a practice, you can't understand what that practice is, even if you know very well the constitutive rules of that practice.

For instance, if you don't understand what a game is, if you don't know the grammar of "game", you can't understand what a game of chess is, even if you know very well the rules of chess.

Curiously, a similar kind of impossibility is described in a short story by Jorge Luis Borges: La busca de Averroes. In this short story, Borges tells us of an impossible research, the research of Averroës. Averroës tried to translate the Poeticsof Aristotle, but being closed within the limits of Islam culture, and not knowing theatre, he couldn't understand the meaning of the two terms 'tragedy' and 'comedy'.

\section{REFERENCES}

BORGES, Jorge Luis. Obras completas. Buenos Aires: Emecé, 1981.

CONTE, Amedeo G. Eidos. An Essay on Constitutive Rules. Poznan Studies in the Philosophy of the Sciences and the Humanities, 11, 1988, pp. 251-257. LÉVI-STRAUSS, Claude. La pensée sauvage. Paris: Plon, 1962.

LORINI, Giuseppe. Dimensioni giuridiche dell'istituzionale. Padua: CEDAM, 2000 .

LORINI, Giuseppe. Oggetto e atto. Torino: Giappichelli, 2008.

MILLER, Dolores. Constitutive Rules and Essential Rules. Philosophical Studies, 39, 1983, pp. 183-197.

ROVERSI, Corrado. Pragmatica delle regole costitutive. Bologna, GEDIT, 2007. 
SCHÄCHTER, Josef. Prolegomena zu einer kritischen Grammatik. Wien: Julius Springer, 1935.

SCHWYZER, Hubert. Rules and Practices. The Philosophical Review, 78, 1969, pp. 451-467.

SEARLE, John Rogers. Speech Acts. An Essay in the Philosophy of Language. Cambridge, Cambridge University Press, 1969.

SEARLE, John Rogers. The Construction of Social Reality. New York: Free Press, 1995.

SEARLE, John Rogers. Making the social world: the structure of human civilization. Oxford: Oxford University Press, 2010.

SWIFT, Jonathan. A Tale of a Tub. In: SWIFT, Jonathan. A Tale of a Tub with Other Early Works (1696-1707). Ed. Louis A. Landa. Oxford: Blackwell, 1960, pp. 241-353.

WITTGENSTEIN, Ludwig. Philosophical Investigations. Oxford: Blackwell, 1953.

WITTGENSTEIN, Ludwig. Philosophische Grammatik. Oxford: Basil Blackwell, 1969.

ZLANIEC, Wojciech. Fathers, Kings and Promises. Husserl and Reinach on the A Priori. Husserl Studies, 9, 1992, pp. 147-177,

ZNAMIEROWSKI, Czeslaw (1924). Podstawowe pojêcia teorji prawa. I. Poznañ, Fiszer i Majewski.

1 The idea that they are rules which create new possibilities of action can already be found in the work of the Polish legal philosopher Czeslaw Znamierowski (1924). (Cf Giuseppe Lorini 2000, 69-81).

2 For this kind of rule, Amedeo G. Conte proposed the name 'eidetic-costitutive rule'. Conte $(1988,252)$ writes: "The eidetic-constitutive rules are those that determine the connotation of those terms that (in the formulation of the rules) designate the praxemes (the units of praxis) which are governed by the rules. For example the rules of chess are eidetic-constitutive because (and in the sense that) they determine the connotation of terms ('bishop', 'castling', 'check', ...) which designate the praxemes (pieces, pragmemes, game situations) of the game".

3 Victory in a game is a very interesting phenomenon for the investigation of institutional reality. Victory in a game like chess presupposes the existence of the institution of chess. You can not win a chess match, if there isn't the institution of the chess game. But the meaning of 'victory' and the meaning of 'defeat' in the sphere of an institution seem go beyond the boundaries of the single institution. The institutions determine the conditions of victory and defeat, and then the extension of the words 'victory' and 'defeat' in the sphere of an institution like chess or soccer. But the intension of the two words is not determined by the institutions that determine the conditions of victory and defeat. Ludwig Wittgenstein (1969) asks: "What do winning and loosing in a game consist in?" And he answers: "Of course not in the game's situation that produces the victory". The meaning of 'victory' and the meaning of 'defeat' seem to go beyond the boundaries of a single institution. Victory and defeat seem not to be institutional concepts, but rather meta-institutional concepts (I owe the phrase 'institutional concept' to Dolores Miller (1981, 191)): they do not have in the institutions their own conditions of possibility, but on the contrary it is they that constitute the conditions of possibility of certain institutions like competitive games. Besides, a sign of the their meta-institutionality is constituted by their trans-institutionality. In fact, whereas the 
conditions of victory and defeat change as we shift from one game to another, the meaning of 'victory' and the meaning of 'defeat' remain unchanged.

4 A similar case is described by Claude Lévi-Strauss (1983, p. 46). Lévi-Strauss describes the case of Gahuku-Gama people from New Guinea "qui ont appris le football, mais qui jouent, plusieurs jours de suite, autant de parties qu'il est nécessaire pour que s'équilibrent exactement celles perdues et celles gagnées par chaque camp". They consider "un jeu comme un rite".

5 Here are four examples of grammatical propositions in the essay of Schwyzer: (i) Promises ought to be kept, (ii) Chess is a competitive game, (iii) Sensations are private, (iv) Expectation is a state.

6 Schwyzer borrows the term 'grammar' from Ludwig Wittgenstein (1953), who writes in $\S \S 371$ e 373: "Essence is expressed by grammar. [...] Grammar tells what kind of object anything is".

\section{¿LAS REGLAS CONSTITUTIVAS PUEDEN CREAR UNA PRÁCTICA?}

\section{RESUMEN}

El autor investiga el papel desarrollado por las reglas constitutivas en la construcción de la realidad social. En particular, niega que, por jemplo, las reglas constitutivas del ajedrez sean condición suficiente de la práctica llamada juego del ajedrez. Para crear una nueva práctica, se necesita también la existencia de la gramática de esa práctica, o sea el sentido mismo de la práctica (por ejemplo: el sentido de juego). Es la gramática de una práctica (y no las reglas constitutivas) la que determina la naturaleza de la práctica misma. El sentido de una práctica no puede ser creado por las reglas constitutivas.

Palabras clave: Reglas constitutivas. Práctica. Ontología social. Hecho institucional.

Submetido: 4 jan. 2016

Artigo convidado 